\title{
Penerapan Metode Variasi Menjelaskan Dengan Media Buku Dongeng Terhadap Perkembangan Kemampuan Numerik (Matematika) Pada Anak Usia Dini Kelompok B
}

\author{
Yaznina Arwani Pakpahan ${ }^{(1)}$ Evrina Lamduma Bancin ${ }^{(2)}$ Elya Siska \\ Anggraini $^{(3)}$, Nasriah ${ }^{(4)}$ \\ (1) Mahasiswa Program Studi PG PAUD FIP UNIMED \\ (2) Mahasiswa Program Studi PG PAUD FIP UNIMED \\ (3) Dosen PG PAUD FIP UNIMED \\ (4) Dosen PG PAUD FIP UNIMED
}

Jln. Williem ISKANDAR Pasar V Medan Estate, Medan, Sumatera Utara, 20371

Email : elyasiskaanggraini@unimed.ac.id

\begin{abstract}
Abstrak : Artikel ini merupakan artikel literatur dengan metode penelitian kepustakaan (library research) dengan menggunakan analisis deskriptif. Hasil yang dianalisis ialah kemampuan anak dalam mengenal konsep dasar matematika. Metode kajian atau analisis yang digunakan ialah analisis induktif. Adapun tujuan dari penelitian ini ialah untuk mengetahui gambaran penerapan metode variasi menjelaskan dengan menggunakan media buku dongeng terhadap pengenalan konsep dasar matematika pada anak usia dini kelompok B. Buku dongeng dapat dirancang dengan menggunakan cerita mencari harta karun. Sehingga anak akan lebih antusias dari sebelumnya dalam belajar matematika. Di dalam buku dongeng, ada beberapa kolom penomoran level baca. Artinya, anak-anak harus mampu menyelesaikan tugastugas mencari harta karun dari buku, setelah itu anak mencari tahu dengan hitungan langkah, sehingga anak berhasil naik ke level selanjutnya.
\end{abstract}

Kata Kunci : Pendidikan Anak Usia Dini, Media Buku Dongeng, Kemampuan Numerik

\section{PENDAHULUAN}

Pendidikan merupakan usaha sadar sepanjang hayat yang dilakukan oleh setiap individu ataupun kelompok untuk mempersiapkan individu lainnya agar dapat memainkan peranan dalam berbagai lingkungan hidup secara tetap untuk masa yang akan datang. UUD 1945 pasal 31 ayat 1 menyebutkan bahwa setiap warga negara berhak mendapatkan pendidikan, dan ayat 3 menegaskan bahwa pemerintah mengusahakan dan menyelenggarakan suatu sistem Pendidikan Nasional yang meningkatkan keimanan dan ketaqwaan serta akhlak mulia dalam rangka mencerdaskan kehidupan bangsa yang diatur dalam undang- 
undang. Oleh karena itu, seluruh komponen bangsa wajib mencerdaskan kehidupan bangsa yang merupakan salah satu tujuan negara Indonesia sebagaimana tertuang dalam naskah pembukaan UUD 1945.Tujuan Negara Indonesia sudah tertuang di dalam alinea keempat UndangUndang Dasar tahun 1945.Salah satu amanat pembukaan UUD 1945 adalah mencerdaskan kehidupan bangsa.Mencerdaskan kehidupan bangsa dapat diwujudkan melalui pendidikan yang berkualitas, dengan fasilitas atau penunjang pendidikan yang memadai. Sejak tahun 2003, upaya mencerdaskan kehidupan bangsa lebih diprioritas kembali dengan mengalokasikan 20\% dari APBN dan APBD sesuai dengan UU No. 20 Tahun 2003 Tentang Sistem Pendidikan Nasional. Berbagai cara telah dilakukan oleh pemerintah dalam upaya melaksanakan amanat mencerdaskan kehidupan bangsa.

Salah satu upaya yang memperlihatkan keseriusan pemerintah adalah dengan mengalokasikan 20\% dari APBN dan APBD yang didasarkan pada UU No. 20 Tahun 2003 Tentang Sistem Pendidikan Nasional. Namun, realita yang dihadapi masyarakat, pelayanan pendidikan masih jauh dari harapan, terjadi keterlambatan pembelajaran matematika yang berada pada Pendidikan Anak Usia Dini ( PAUD ). Pada kenyataannya, di Indonesia proses pembelajaran anak PAUD masih menjadi permasalahan dalam beberapa tahun terakhir ini. Hal ini dikarenakan pola pembelajaran cenderung berorientasi akademik dan menganggap bahwa konsepkonsep yang ada pada diri anak tidak berkembang secara spontan melainkan harus ditanamkan dan diserap oleh anak melalui perlakuan orang dewasa, dimana guru adalah subjek dan anak adalah objek dari proses pembelajaran. Dalam hal ini guru mengajar anak diajar, guru mengerti semuanya dan anak tidak tahu apa-apa, guru berpikir dan anak dipikirkan, guru berbicara dan anak mendengarkan, guru mendisiplinkan dan anak didisiplin, guru memilih dan mendesakkan pilihannya dan anak hanya mengikuti, guru bertindak dan anak hanya membayangkanbertindak lewat cerita guru, guru memilih isi program dan anak menjalaninya begitu saja. Hal tersebut di atas bertentangan dengan hakikat pembelajaran di PAUD yang menekankan pembelajaran yang aktif. 
Dengan tidak tersedianya media pembelajaran matematika untuk anak usia dini, guru dan orang tua mengalami kesulitan dalam mengajarkan pembelajaran matematika untuk anak-anaknya. Padahal, matematika haruslah diajarkan sejak dini sesuai yang dikatakan oleh Hans Van Luit dan Bernadette Van De Rijt ( Vl\& Vdr) yaitu memulai belajar matematika di sekolah dasar biasa pada 6 tahun mungkin sudah terlambat.Dengan demikian, guru dan orang tua membutuhkan media pembelajaran matematika yang sederhana dan mudah dalam penggunaannya dalam pembelajaran matematika.Dalam memenuhi tugas sebagai seorang pendidik, guru memerlukan berbagai keterampilan dalam variasi mengajar, beberapanya ialah menyediakan media edukatif, metode yang sesuai, dan strategi pembelajaran yang efektif dan efisien. Oleh karena itu, penulis mengangkat permasalahan kajian literature terkait penggunaan variasi menjelaskan dan media belajar yang mampu mendukung kemampuan numeric anak, dengan judul kajian "Penerapan Metode Variasi Menjelaskan Dengan Media Buku Dongeng Terhadap Pengenalan Konsep Dasar Matematika pada Anak Usia Dini Kelompok B”. Kajian literature ini bertujuan untuk mengetahui penerapan metode variasi menjelaskan yang paling tepat untuk mendukung kemampuan belajar matematika anak.

\section{KAJIAN LITERATUR}

Pendidikan anak usia dini menurut Undang-Undang No 20 Tahun 2003 Tentang Sistem Pendidikan Nasional menyatakan bahwa PAUD adalah suatu upaya pembinaan yang ditunjukan kepada anak sejak lahir sampai dengan usia 6 tahun yang dilakukan melalui pemberian ransangan pendidikan untuk membantu pertumbuhan dan perkembangan jasmani dan rohani agar anak memiliki kesiapan dalam memasuki pendidikan lanjut. Menurut Solehuddin (2000) anak usia dini merupakan "sosok individu yang sedang mengalami proses perkembangan dengan sangat pesat dan fundamental bagi kehidupan selanjutnya”. Sedangkan menurut Anwar dan Ahmad (2003: 2) PAUD adalah pendidikan yang berfungsi untuk membantu pertumbuhan dan perkembangan jasmani, serta perkembangan kejiwaan anak yang dilakukan di dalam maupun di luar lingkungan keluarganya. 
Ada beberapa alasan mengapa PAUD menjadi penting untuk negeri ini ke depannya, diantaranya ialah: a) dalam dimensi keisupan berbangsa dan bernegara, anak adalah penentu kehidupan di masa mendatang, b) usia kelahiran hingga 6 tahun merupakan usia kritis bagi perkembangan semua anak, c) penelitian menunjukkan bahwa sejak lahir anak memiliki kurang lebih 100 miliar sel otak. Dengan adanya PAUD maka kecerdasan pada otak anak akan terus terstimulus dan terasah sehingga kemampuan anak aka lebih dinamis. Nasriah (2013: 3).

Pada umumnya tujuan PAUD adalah mengembangkan berbagai potensi anak sejak dini sebagai persiapan untuk hidup dan dapat menyesuaikan diri dengan lingkungannya. Tujuan PAUD dalam Depdiknas (2012) antara lain adalah: a) kesiapan anak memasuki pendidikan lebih lanjut, b) mengurangi angka mengulang kelas, c) mengurangi angka putus sekolah, d) mempercepat pencapaian wajib belajar pendidikan dasar 9 tahun, e) meningkatkan mutu pendidikan, f) mengurangi angka buta huruf muda, g) memperbaiki kesehatan dan gizi anak usia dini, dan h) meningkatkan indeks pembangunan manusia (IPM).

Banyak ahli Matematika mengatakan "Mathematics is the queen as well as the servant of all science" (Matematika adalah ratu sekaligus pelayan semua ilmu pengetahuan). Ungkapan tersebut jelas menggambarkan bahwa Matematika menduduki posisi sentral dalam kancah dunia ilmu pengetahuan (Susilo, 2012).Matematika dan logika pada dasarnya adalah ilmu yang mempelajari dan merumuskan secara sistematis kaidah-kaidah yang mengatur bagaimana manusia bernalar secara valid.Penalaran adalah salah satu kegiatan berpikir manusia untuk menarik kesimpulan yang nantinya dapat dirumuskan.Matematika pada dasarnya bekerja dengan himpunan, yaitu sekumpulan objek konkret maupun abstrakyang mempunyai ciri-ciri tertentu, Susilo $(2012 ; 8)$.

Meskipun melalui tahapan dan teori-teori mendalam, namun matematika merupakan suatu materi pelajaran yang harus ada di setiap jenjang pendidikan, baik yang diterapkan secara langsung, maupun secara terpadu. Roger Bacon, filsuf dari Inggris, dengan tegas menyatakan bahwa mengabaikan matematika 
sama halnya mencederai semua pengetahuan karena siapapun yang mengabaikan matematika tidak akan mampu memahami ilmu pengetahuan lain di alam semesta ini (Wijaya, 2014). Matematika juga merupakan materi yang menjadi dasar kecerdasan anak sejak dini. Salah satu aspek perkembangan anak usia dini adalah perkembangan kecerdasan logicmathematic. Prasetyo dan Andriyani (2009) mengemukakan bahwa kecerdasan matematika sebagai kapasitas untuk untuk menggunakan angka, berpikir logis untuk suatu kasus.Sedangkan menurut Yus (2011; 71), kecerdasan logika matematika adalah kemampuan untuk memahami dasar-dasar operasional yang berhubungan dengan angka serta prinsip-prinsip dengan kepekaan melihat pola dan hubungan sebab akibat dan pengaruh.Jadi, dapat dipahami kecerdasan logika matematika adalah kemampuan berpikir logis dan analisis terhadap suatu kasus yang sedang dihadapi.

Terkait dengan pembelajaran media adalah segala sesuatu yang dapat digunakan untuk menyampaikan pesan dari pengirim pesan kepada penerima pesan sehingga dapat merangsang pikiran, minat dan perhatian anak didik untuk mencapai tujuan pendidikan yang optimal. Matemarika sebagai media belajar, merupakan suatu inovasi yang akan mendukung perkembangan kecerdasan logika matematika anak. .Terkait dengan pembelajaraan media menurut Dhieni (2009:10.3) adalah segala sesuatu yang dapat digunakan untuk menyampaikan pesan dari pengirim pesan kepada penerima pesan sehingga dapat merangsang pikiran, perasaan, dan perhatian anak didik untuk tercapainya tujuan pendidikan.Menurut Gagne dalam Dhieni (2009:10.3) media adalahberbagai jenis komponen dalam lingkungan anak didik yang dapat memotivasi anak didik untuk belajar.

Terkait matematika sebagai media pembelajaran menurut pusat pembinaan dan pengembangan bahasa dalam Sujiono (2008:11.3) matematika adalah ilmu tentang bilangan-bilangan, hubungan antara bilangan dan prosedur operasional yang digunakan dalam penyelesaian persolan mengenai bilangan.Sedangkan menurut Suriasumantri dalam Sujiono (2008:11.3) matematika adalah bahasa yang melambangkan serangkaian makna dari pernyataan yang ingin disampaikan.Lambang-lambang matematika bersifat artifisial dan baru 
memiliki arti setelah sebuah makna diberikan kepadanya.Dengan demikian dapat disimpulkan bahwa matematika sebagai media adalah alat atau sarana untuk menyokong kemampuan anak dalam mengenal lambang bilangan, menggunakan angka-angka, dan memecahkan masalah.Menurut Sujiono (2008:11.5) secara umum permainan matematika di TK bertujuan agar anak mengetahui dasar-dasar pembelajaran berhitung dalam suasana yang menarik, aman, nyaman, dan menyenangkan, sehingga diharapkan nantinya anak akan memiliki kesiapan dalam mengikuti pembelajaran matematika yang sesungguhnya disekolah dasar.

Metode bercerita melalui mendongeng adalah cerita zaman lampau yang berbentuk prosa yang diceritakan secara turun temurun (Basra, 2012).Sedangkan menurut Priyono (2006) dongeng merupakan kisah khayalan atau cerita yang mengada-ada serta tidak masuk akal dan dapat ditarik manfaatnya.Dongeng juga bisa berupa kisah fiksi yang digunakan sebagai media dalam pembelajaran anak, sebab anak akan merasakan petualangan dalam imajinasinya melalui dongeng.

\section{METODE PENELITIAN}

Artikel ini merupakan artikel literatur dengan metode penelitian kepustakaan (library research) dengan menggunakan analisis deskriptif.Analisis deskriptif dipilih karena peneliti ingin menggambarkan objek yang diteliti secara alamiah.Hasil yang dianalisis ialah kemampuan anak dalam mengenal konsep dasar matematika. Alasan pemilihan metode variasi menjelaskan dengan menggunakan media buku dongeng ialah, karena anak usia dini merupakan individu yang gemar bercerita dan mendengar cerita umunya, pada usia ini belum saatnya bagi mereka menghitung atau mempelajari matematika secara langsung, sehingga diperlukan adanya media yang inovatif serta strategi pembelajaran yang kreatif melalui buku dongeng. Metode kajian atau analisis yang digunakan ialah analisis induktif.Augiyono (2005) menjelaskan bahwa analisis data kualitatif bersifat induktif, yaitu analisis berdasarkan data atau hasil penelitiannya sebelumnya, lalu dikembangkan. Adapun tujuan dari penelitian ini ialah untuk mengetahui gambaran penerapan metode variasi 
menjelaskan dengan menggunakan media buku dongeng terhadap pengenalan konsep dasar matematika pada anak usia dini kelompok B.

\section{HASIL DAN PEMBAHASAN}

Ada beberapa manfaat mendongeng bagi anak, diantaranya : 1) Memicu kekuatan berpikir, semua cerita yang baik, memiliki alur yang baik. Alur cerita anak-anak sebaiknya sederhana, karena karakter atau alur cerita yang terlalu rumit, akan membuat anak bingung; 2) Merangsang kemampuan visual anak; 3) Meningkatkan kata-kata ataupun pembendaharaan kosa kata anak melalui cerita dan dongeng; serta 4) Memupuk Pengertian terhadap Orang Lain, sebab tokoh-tokoh di dalam buku cerita akan terasa hidup, apabila dibubuhi kemampuan membaca yang mengagumkan.

Menurut Cakra (2012) persiapan mendongeng ada beberapa tahap yaitu sebagai berikut: 1) Memilih dongeng, 2) Membaca tuntas dan berulang-ulang 3.) Meringkas cerita dongeng, serta 4) Kembali mengingat-ingat kisah dan tujuan yang ingin diperoleh. Cara merancang buku dongeng dapa dilakukan seperti di atas, namun akan lebih baik jika buku dongeng dipenuhi dengan gambar ilustrasi yang full color guna untuk menambah minat anak untuk membanca buku dongeng tersebut, terlebih lagi anak usia dini belum saatnya mahir dalam membaca, dengan adanya gambar yang menarik maka anak akan memahami cerita walau hanya melalui aluran gambar saja.

Menurut hasil penelitian dari jurnal media edukasi, pengenalan konsep matetaika dasar meningkat setelah anak-anak melaksanakan pembelajaran dengan metode variasi menjelaskan melalui dongeng.Hal ini dikarenakan faktor pendukung dalam penerapan metode mendongeng ialah: 1) kegiatan mendongeng dilakukan dengan menggunakan media-media yang menarik dan inovatif, 2) adanya kemampuan atau keterampilan pendongeng dalam mengaitkan cerita dengan konsep dasar matematika, 3) anak memiliki rasa ingin tahu yang besar, serta 4) adanya partisipasi dan kerjasama yang baik anatara para guru, peneliti, dan kepala sekolah.

Buku dongeng dapat dirancang dengan menggunakan cerita mencari harta karun. Sehingga anak akan lebih antusias dari sebelumnya dalam belajar 
matematika. Di dalam buku dongeng, ada beberapa kolom penomoran level baca. Artinya, anak-anak harus mampu menyelesaikan tugas-tugas mencari harta karun dari buku, setela itu anak mencari tahu dengan hitungan langkah, sehingga anak berhasil naik ke level selanjutnya. Ada beberapa halyang menjadi dasar dalam keterampilan model belajar, yaitu: pijakan lingkungan bermain, pijakan sebelum bermain, pijakan selama bermain, dan pijakan setelah bermain. Untuk kegiatan bercerita menggunakan buku dongeng ini bisa dilaksanakan pada pijakan sebelum bermain dan saat bermain.Mula-mula, guru bercerita untuk memulai pembelajaran, seperti menyampaikan tema hari ini.Lalu, guru menanyakan kabar anak dengan penuh semangat.Setelah brdoa dan lainnya, guru mengajak anak untuk bermain mencari harta karun dengan panduan buku dongeng. Dengan begitu, anak akan semakin faham cara berhitung dan mengenal numeric dasar secara bertahap. Selain itu, melalui media buku dongeng, anak menjadi lebih semangat, tertarik dengan warna buku, dan mengurangi depresi dini anak terhadap pembelajaran matematika. Terakhir, guru meminta anak untuk menceritakan kembali apa isi dongeng, lalu anak menyampaikan pesan, kesannnya selama metode variasi menjelaskan dengan menggunakan media buku dongeng.

\section{SIMPULAN}

Pendidikan merupakan usaha sadar sepanjang hayat yang dilakukan oleh setiap individu ataupun kelompok untuk mempersiapkan individu lainnya agar dapat memainkan peranan dalam berbagai lingkungan hidup secara tetap untuk masa yang akan datang.Menurut Solehuddin (2000) anak usia dini merupakan "sosok individu yang sedang mengalami proses perkembangan dengan sangat pesat dan fundamental bagi kehidupan selanjutnya".Ada beberapa manfaat mendongeng bagi anak, diantaranya : 1) Memicu kekuatan berpikir, semua cerita yang baik, memiliki alur yang baik. Alur cerita anak-anak sebaiknya sederhana, karena karakter atau alur cerita yang terlalu rumit, akan membuat anak bingung; 2) Merangsang kemampuan visual anak; 3) Meningkatkan katakata ataupun pembendaharaan kosa kata anak melalui cerita dan dongeng; serta 4) Memupuk Pengertian terhadap Orang Lain, sebab tokoh-tokoh di dalam buku cerita akan terasa hidup, apabila dibubuhi kemampuan membaca 
yang mengagumkan. Buku dongeng dapat dirancang dengan menggunakan cerita mencari harta karun. Sehingga anak akan lebih antusias dari sebelumnya dalam belajar matematika. Di dalam buku dongeng, ada beberapa kolom penomoran level baca. Artinya, anak-anak harus mampu menyelesaikan tugastugas mencari harta karun dari buku, setela itu anak mencari tahu dengan hitungan langkah, sehingga anak berhasil naik ke level selanjutnya.

\section{DAFTAR PUSTAKA}

Cahaya, I Made, E, dan ChristianiEP. (2017). "Efektivitas Mendongeng dalam MeningkatkDan Kemampuan Matematika Anak Usia Dini”. Jurnal Media Edukasi.Volume 1, Nomor 2.

Hartini Puji. (2012). Peningkatan Kemampuan Matematika Anak Melalui Media Permainan Memancing Angka di Taman Kanak-Kanak Fathimah Bukareh Agam.Jurnal Pesona PAUD Vol.I No. 1.

Nasriah dan Dedy Husrizal.(2013). Konsep Dasar PAUD. Medan: Unimed Press

Susilo, Frans. (2012). Landasan Matematika. Yogyakarta: Graha Ilmu

Wijaya, Ariyadi. (2014). Asyiknya Belajar Matematika.Yogyakarta: Graha Ilmu,

Yus, Anita. (2015). Model Pendidikan Anak Usia Dini. Jakarta: Prenamedia Group

Nuraini, Febritesna. 2014. "Pelaksanaan Pengenalan Konsep Dasar Matematika Melalui Metode Bercerita dengan Memanfaatkan Lingkungan Sebagai Sumber Belajar di PAUD Terpadu Nuraini Aisyah Yogyakarta”. Jurnal AdMathEdu. Vol 4, No, 2 